\title{
Andrzej Chwalba Samobójstwo Europy. Wielka Wojna 1914- 1918, Wydawnictwo Literackie, Kraków 2014, ss. 645+2 nlb, il., 7 mapek
}

Po pracach Jana Dąbrowskiego ${ }^{1}$ i Janusza Pajewskiego ${ }^{2}$ otrzymaliśmy trzecie polskie opracowanie dziejów I wojny światowej, wprawdzie też obszerne, ale niedorównujące rozmiarami dziełom poprzedników. J. Dąbrowski koncentrował się przede wszystkim na przebiegu działań wojennych, u J. Pajewskiego co najmniej równorzędne miejsce zajmują sprawy polityczne. A. Chwalba rozszerzył tematykę Wielkiej Wojny o kilka nowych wątków, w tym o aspiracje narodów „niepaństwowych" i ich poczynania zmierzające do posiadania własnych struktur państwowych, intensywne zwłaszcza $\mathrm{w}$ dwu ostatnich latach wojny i ukoronowane w większości przypadków odzyskaniem lub uzyskaniem niepodległości. Wiele miejsca zajmują też sprawy bliższego i dalszego zaplecza frontu, poczynając od losów rannych i chorych żołnierzy czy jeńców wojennych. Omówiono finanse wojenne, migracje milionów ludności cywilnej i oraz życie $\mathrm{w}$ państwach uczestniczących $\mathrm{w}$ tych zmaganiach i na okupowanych przez nie terenach. W porównaniu z opracowaniami poprzedników praca A. Chwalby jest też mniej europocentryczna.

To poszerzenie problematyki wiąże się $\mathrm{z}$ rozwojem badań $\mathrm{w}$ ostatnich dziesięcioleciach, co niewątpliwie wpływa na pełniejszy obraz pierwszego w XX stuleciu wielkiego konfliktu zbrojnego o światowym zasięgu. Wyjście poza problematykę militarno-polityczną ma daleko idące konsekwencje. Z jednej strony czytelnik otrzymuje bardziej wszechstronny wizerunek wydarzeń z lat 1914-1918, z drugiej autorzy wkraczają często na obszary dalekie od ich własnych badań, czego skutkiem są mniejsze lub większe potknięcia i błędy, niekiedy dość zaskakujące.

Tak jest też w przypadku recenzowanej książki. Struktura polityczna dualistycznej monarchii naddunajskiej i jej instytucji państwowych nie od dzisiaj sprawia kłopoty wielu autorom, w tym także z terenów byłej Galicji. Andrzej Chwalba konsekwentnie pisze o c. k. monarchii i jej c. k. armii, co nie zawsze jest zasadne, bowiem od roku 1867 państwo Habsburgów miało wspólne, austro-węgierskie „cesarskie i królewskie” (c. i k) instytucje (ministerstwa spraw zagranicznych, wojny i finansów),

${ }^{1}$ J. Dąbrowski, Wielka wojna 1914-1918 na podstawie najnowszych źródet, t. 1-2, Warszawa 1937, ss. 1016.

2 J. Pajewski, Pierwsza wojna światowa 1914-1918, Warszawa 1991, ss. 840. 
„cesarsko-królewskie” (c. k.) na terenie Cesarstwa Austriackiego, zwanego potocznie Przedlitawią (m. in. rząd, parlament, obrona krajowa, namiestnictwa) i „królewsko-węgierskie” (k. w.) w granicach Korony św. Stefana, czyli Królestwa Węgierskiego - „Zalitawii" (rząd, parlament, honwedzi). Nie było wspólnego rządu ani parlamentu, a sprawy dotyczące obu części monarchii uzgadniano w ramach tzw. delegacji rządów bądź parlamentów ${ }^{3}$. Wspólny był wprawdzie monarcha, ale osobna koronacja na cesarza Austrii i króla Węgier. Ostatni z panujących Habsburgów był Karolem I jako cesarz Austrii i Karolem IV jako król Węgier. Co do sił zbrojnych, to w dualistycznej monarchii istniała ,,[...] austro-węgierska, armia cesarska i królewska (kaiserlich und königlich, k. u. k. c. i k.) oraz cesarsko-królewska obrona krajowa, czyli rezerwa (kaiserlich königliche Landwehr, k. k. - c. k. po polsku) oraz królewsko-węgierska (kiraly magyar honved) $[\ldots]^{\prime \prime}$. Struktury wojskowe na poziomie armii i korpusu były wyłącznie c. i k., natomiast wchodzące w ich skład dywizje, brygady i pułki mogły być zarówno austro-węgierskie (c. i k.) austriackie (c. k.), jak i węgierskie (k. w.).

Przy omawianiu celów wojennych poszczególnych państw napisano iż „Rosja marzyła [...] o zdobyciu ziem, które uważała za rosyjskie, takich jak Galicja Wschodnia i Bukowina.” (s. 59) Za część „Rusi Ujarzmionej”, którą wojska carskie miały zdobyć w ramach „wielkiej wojny wyzwoleńczej 1914 r.”, uznawano także tzw. Ruś Węgierską (Zakarpacką). Przyłączenie „Rusi Ujarzmionej” do państwa Mikołaja II miało zakończyć proces „zbierania ziem ruskich” zapoczątkowany w XIV w. przez Iwana Kalitę ${ }^{5}$.

Pozostając przy sprawach sił zbrojnych, to wojsko rosyjskie nie było armią „Jego Imperatorskiej Wysokości” (s. 72), ale "Jego Imperatorskiej Mości" czyli cara Mikołaja I, a nie wielkiego księcia Mikołaja Mikołajewicza. Tytuł „Mości” (ros. Wieliczestwa, niem. Majestät), jakkolwiek by to po polsku nie brzmiało, przysługiwał (i nadal przysługuje) osobom panującym, a innym członkom dynastii właśnie „Wysokość” (ros. Wysoczestwo, niem. Hoheit). Na s. 267 jest mowa o tym, że „Dowódcą armii niemieckoaustriacko-wegierskiej został generał Falkenhayn..." Nie było armii niemiecko-austriacko-węgierskiej, a tylko na użytek poszczególnych operacji połączone siły zbrojne państw centralnych.

${ }^{3}$ Zob. m.in.: H. Batowski, Rozpad Austro-Wegier 1914-1918. (Sprawy narodowościowe i działania dyplomatyczne), wyd. 2, Kraków 1982, s. 15, 28-40; H. Wereszycki, Historia Austrii, Wrocław 1972, s. 253.

${ }^{4}$ J. Pajewski, op. cit., s. 155

${ }^{5}$ W. Osadczy, Święta Ruś. Rozwój i oddziaływanie idei prawosławia w Rosji, Lublin 2007, s. 207-282. 
Sporo niejasności tkwi w zdaniu: „W kolejnych latach, mimo tworzenia nowych, tak zwanych marszowych batalionów, armia [austrowęgierska] była mniej liczna od tej, która wyruszyła na wojnę" (s. 146). W czasie wojny pułki piechoty i kawalerii c. i k. armii miały na zapleczu, najczęściej $\mathrm{w}$ miejscu stacjonowania $\mathrm{w}$ czasie pokoju (ale także na terenach okupowanych), swoje formacje zapasowe (Ersatzbaonen w piechocie i Ersatzschwadronen w kawalerii, a także formacje zapasowe innych rodzajów broni), zwane też kadrami, w których formowano (z rekrutów, ozdrowieńców, a od wiosny 1918 r. także jeńców, którzy wrócili z niewoli rosyjskiej) właśnie kolejne bataliony marszowe (Marschbaonen) (w ich składzie kompanie marszowe - Marschkompanien) wysyłane jako uzupełnienie macierzystych pułków na froncie ${ }^{6}$. W Podstawowej bibliografii Autor umieścił J. Haška Losy dobrego żotnierza Szwejka czasu wojny światowej tł. Antoni Kroch, Kraków 2009. Otóż całe końcowe partie tej książki to właśnie podróż Szwejka na front rosyjski w ramach 11 kompanii marszowej, batalionu N, c. i k. 91. pułku piechoty z Czeskich Budziejowic. Akcja powieści Haška urywa się w lipcu 1915 roku, trudno zatem zgodzić się z opinią Autora, iż ilustruje ona "porzucanie obowiązków żołnierskich [...] także w armii podwójnej monarchii w drugiej połowie 1918 roku" (s. 462).

Wiele nieścisłości dotyczy działań wojennych. Na s. 137 znajduje się opis walk dwu armii austro-węgierskich w sierpniu 1914 r. w południowo-wschodniej Kongresówce: „21 sierpnia siły zbrojne osiągnęły stan gotowości bojowej, a 23 sierpnia 1. armia generała Victora Dankla pomaszerowała w kierunku Lublina, odnosząc po drodze taktyczne zwycięstwo pod Kraśnikiem (po tej bitwie generał otrzymał tytuł hrabiowski i teraz był znany jako generał Victor Dankl [Graf -JL] von Kraśnik), kolejne zaś z 26 na 27 sierpnia pod Komarowem, ścierając się z oddziałami 4. i 5. armii rosyjskiej. Wspierały ją oddziały z 4 . armii generała Moritza von Auffenberga, które przesuwały się w kierunku Chełma."

W literaturze przedmiotu działania te to I bitwa pod Kraśnikiem (2325 sierpnia 1914 r.) między 4. armią rosyjską i 1. austro-węgierska, oraz bitwa pod Komarowem (26 sierpnia-2 września 1914 r.) między c. i k. 4. armią i 5. armią rosyjską. Zwycięski dowódca c. i k. 4. armii otrzymał tytuł barona (Freiherr von Komarów), a bitwa komarowska doczekała się dwu

${ }^{6}$ Szerzej o tym R. G. Plaschka, H. Haselssteiner, A. Suppan, Innere Front. Militärassistenz, Widerstand und Umsturz in der Donaumonarchie 1918, Bd. 1-2, Mǘnchen 1974. 
monografii ${ }^{7}$ oraz wiele miejsca $\mathrm{w}$ opracowaniach szerzej ujmujących początkową fazę zmagań rosyjsko-austriackich ${ }^{8}$. Walki „,z 26 na 27 sierpnia” są określane w literaturze jako „bitwa pod Zamościem” - pierwsza faza bitwy komarowskiej w której c. i k. 1. armia nie miała żadnego udziału9.

Wiele drobnych potknięć z zakresu terminów wojskowych, czy budowlanych może wprowadzać w błąd słabiej zorientowanego czytelnika. „Normą stało się niewykonywanie rozkazów przez żołnierzy, nieoddawanie honorów wojskowych wyższym stopniem, odmawianie salutowania" (s. 253). Salutowanie to nic innego, jak oddawanie honorów. Na s. 346-347 „[...] konstruowano ziemianki podparte okraglakami, czyli balami [...]”. Bal to jednak nie okragglak.

W interesującej partii o jeńcach wojennych należałoby chociażby wspomnieć o powrocie z Rosji po drugim traktacie brzeskim (3 marca 1918 r.) jeńców z armii niemieckiej i austro-węgierskiej. Z tej ostatniej w niewoli rosyjskiej do grudnia 1917 r. znalazło się 54146 oficerów i ok. 2057000 podoficerów i szeregowców. Do końca czerwca 1918 r. wróciło z Rosji ok. 517000 jeńców ${ }^{10}$. Większość $\mathrm{z}$ nich znalazła się $\mathrm{w}$ formacjach zapasowych, w których po przeszkoleniu usiłowano uformować z byłych jeńców bataliony marszowe i wysłać na front (przeważnie włoski), co było powodem buntów m. in. na terenie okupacji austriackiej w Królestwie Polskim w Lublinie, Kraśniku, Kielcach, Piotrkowie i Zamościu. Bunty te były dalszym ciągiem wystąpień antywojennych, które objęły c. i k. monarchię i okupowane przez jej siły zbrojne tereny Kongresówki od stycznia 1918 r. Były to zarówno bunty żołnierskie (marynarze w Kotorze), jak też manifestacje i strajki ludności cywilnej ${ }^{11}$.

W nowatorskiej w literaturze polskiej partii o Wojnie cywili wiele miejsca poświęcono sprawom finansów. Warto tu może dodać, że pewną

${ }^{7}$ E. Izdebski, Bitwa pod Komarowem. 26 sierpnia-2 września 1914 r., Warszawa 1931; S. Vojcechovsky, Bitwa u Tomaszowa a Komarowa, Praha 1935.

${ }^{8}$ M. in.: А. Белой, Галициииская битва, Москва-Денинград 1929; ÖsterreichUngarns letzter Krieg 1914-1918, 2 Aufl., Bd. 1, Wien 1931; J. Bator, Wojna galicyjska. Działania armii austro-węgierskiej na froncie pótnocnym (galicyjskim) w latach 19141915, Kraków 2005.

${ }^{9}$ E. Izdebski, Bitwa pod Zamościem 26-27 sierpnia 1914 r., „Bellona” 1929, t. 33.

${ }^{10}$ R. G. Plaschka, H. Haselsteiner, A. Suppan, op. cit., Bd. 1, s. 278-280. Z armii niemieckiej w niewoli rosyjskiej znalazło się 2082 oficerów i aspirantów oficerskich oraz 165000 żołnierzy. Jednym z jeńców z c. i k. armii był przywoływany czterokrotnie w tekście książki Jaroslav Hašek, potem legionista czeski w Rosji, a następnie komisarz polityczny w Armii Czerwonej na Syberii i wysoki funkcjonariusz radziecki w Omsku.

${ }^{11}$ Ibidem, passim. 
rolę w finansowaniu działań wojennych odegrały tereny okupowane. Ich mieszkańców obciążono kosztami administracji okupacyjnej i utrzymania wojsk stacjonujących na zajętym terenie. Okupanci mieli też prawo konfiskowania finansów oraz majątku państwa nieprzyjacielskiego, a także czerpania korzyści z zarządzania tym majątkiem i jego eksploatacji (lasy państwowe, dobra skarbowe, itp.). Pewną rolę odegrały też kontrybucje, czyli przymusowe świadczenia $w$ pieniądzach lub naturze, za które nie płacono, i rekwizycje, za które wraz z trwaniem wojny płacono coraz rzadziej, zwłaszcza na terenie nieprzyjacielskim.

W partii dotyczącej siły roboczej warto może wspomnieć o zatrzymaniu $\mathrm{w}$ Niemczech po wybuchu wojny robotników cudzoziemskich (głównie z Kongresówki), a także o zmuszaniu do pracy, zwłaszcza przy budowie sieci komunikacyjnej i różnego rodzaju umocnień, ludności okupowanych terenów. Barwne opisy wojennej codzienności i problemów związanych z wyżywieniem można wzbogacić o informacje o wprowadzeniu dni bezmięsnych, a nawet bezmącznych. W partii o czarnym rynku warto dodać, że obejmował on także przemyt, zarówno przez dotychczasowe granice (chociażby między Galicją a Królestwem), jak i przez nowe kordony okupacyjne. Przy wzmiance o kontyngentach na terenach okupowanych warto wyjaśnić ich istotę. W praktyce został zlikwidowany wolny handel większością artykułów żywnościowych. Producenci zostali zobowiązani do dostarczenia wyznaczonych ilości płodów rolnych po sztywnych cenach, znacznie niższych od czarnorynkowych. Wyznaczono także normy spożycia dla producentów rolnych, ich rodzin, inwentarza żywego i na zasiew, chociaż w praktyce i te ilości nie były wolne od rekwizycji. Był to jeden z elementów głębokiej ingerencji państwa w życie gospodarcze $^{12}$.

Przy sprawach okupacji warto zaznaczyć, że regulowała je, przyjęta w 1907 r. na II Konferencji Haskiej, tzw. IV konwencja haska, a zwłaszcza stanowiący jej część „,Regulamin praw i zwyczajów wojny lądowej”, określający prawa i obowiązki okupanta ${ }^{13}$. Z reguły walczące strony stosowały się do tych norm prawa międzynarodowego, które stanowiły m. in.,

${ }^{12}$ F. Hanusch, Die Regelung der Arbeiterverhältnisse im Kriege, Wien 1927; H. Loewenfeld-Russ, Die Regelung der Volksernährung im Kriege, Wien 1926; w odniesieniu do ziem polskich Polska w czasie Wielkiej Wojny, t. 2-4, red. M. Handelsman, Warszawa 1932-1939.

${ }^{13}$ Polski tekst konwencji w „Dzienniku Ustaw Rzeczypospolitej Polskiej” 1927, nr 21 oraz w Wyborze źródeł do nauki prawa międzynarodowego, opr. B. Winiarski, Kraków 1938, s. 103-112. Omówienie postanowień zawartych w IV Konwencji haskiej w sprawach okupacji wojennej zawierają podręczniki prawa międzynarodowego. 
że ludność zajętego terenu nieprzyjacielskiego zachowuje wcześniejszą przynależność państwowa że nadal obowiązuje na okupowanym obszarze dotychczasowe prawo (chociaż okupant mógł je zmienić i wprowadzić własne) i że nie wolno na zajętym terytorium państwa nieprzyjacielskiego prowadzić przymusowego werbunku do armii okupanta.

W części dotyczącej rosyjskiej okupacji Galicji napisano, że „Władze carskie uznały wschodnią część Galicji oraz Łemkowszczyznę za odwieczne ziemie rosyjskie i dokonały ich inkorporacji do cesarstwa Romanowów" (s. 539). Jak dotychczas informacja ta nie ma potwierdzenia w źródłach ani opracowaniach, nie stwierdzono także jej praktycznych konsekwencji, np. $\mathrm{w}$ postaci przymusowego poboru do armii rosyjskiej. Stwierdzenie, że rosyjskie władze okupacyjne w Galicji „,sukcesywnie likwidowały struktury administracji habsburskiej" także wymaga komentarza: administracja na poziomie namiestnictwa i starostw powiatowych została ewakuowana przez władze austriackie przed wkroczeniem Rosjan. Pozostała zatem administracja samorządowa na poziomie gmin miejskich i wiejskich, którą władze okupacyjne podporządkowały sobie, ale na ogół nie likwidowały, chociażby z przyczyn praktycznych - to te struktury obciążano kontrybucjami i rekwizycjami i polecano im wykonywanie rozporządzeń nowych władz - ich likwidacja groziła pogłębieniem i tak niemałego chaosu. Jako przykład może posłużyć zachowanie samorządowej administracji Lwowa, kierowanej przez prezydenta Rutowskiego. ${ }^{14}$ Następne zdanie, że „Do Rosji [władze okupacyjne] deportowały niektórych polityków ukraińskich z Mychajłą Hruszewskim oraz arcybiskupem Cerkwi greckokatolickiej Andrzejem Szeptyckim na czele" - także trudno zostawić bez komentarza. Hruszewski, mimo że od 1894 r. był profesorem Uniwersytetu Lwowskiego, zachował rosyjską przynależność państwową i po wybuchu wojny groziło mu jako „poddanemu państwa nieprzyjacielskiego” internowanie w Austrii. W sierpniu 1914 r. przebywał na letnim wypoczynku w Krzyworówni w Karpatach Wschodnich, skąd przez Wiedeń, Węgry i Rumunię jesienią 1914 r. dotarł do Kijowa. Tam został zatrzymany przez władze rosyjskie i wywieziony do Kazania, gdzie pod nadzorem policyjnym przebywał do upadku caratu ${ }^{15}$.

${ }^{14}$ W. Najdus, Galicja w pierwszym roku działań wojennych, [w:] Historia Polski, t. 3, cz. 3, 1914-1918 red. Ż. Kormanowa i W. Najdus, Warszawa 1974, s. 79-82.

${ }^{15}$ Droga Hruszewskiego z Krzyworówni do Kijowa była dość skomplikowana. Po przybyciu do Wiednia wyjechał do neutralnych jeszcze Włoch, gdzie prowadził kwerendę archiwalną. Stamtąd ponownie pojechał do Wiednia i wreszcie do Kijowa. Wśród motywów jego powrotu do Rosji wymienia się zarówno obawę przed internowaniem w Austrii, jak i rozporządzenie władz rosyjskich, w którym zobowiązywano poddanych cara do powrotu w granice Cesarstwa w ciągu sze- 
Pewien niedosyt pozostawia partia poświęcona niemieckiej i austriackiej okupacji w Kongresówce. Trudno nie zgodzić się z opinią o „bezwzględnej eksploatacji ekonomicznej", ale też warto dodać, iż owa eksploatacja spowodowała odbudowę, a także rozbudowę zniszczonej przez Rosjan i rzadkiej sieci komunikacyjnej - lądowej (drogi bite i żelazne) i wodnej (żegluga na Wiśle). Sieć kolejową odbudowano jako normalnotorową (w Kongresówce, poza koleją warszawsko-wiedeńską, istniały linie szerokotorowe), a w czasie samej okupacji austriackiej zbudowano $249 \mathrm{~km}$ normalnotorowej linii kolejowej i 314 km wąskotorówek, w tym uruchomiono cztery połączenia między zaborem rosyjskim a Galicją ${ }^{16}$. Kongresówka nie była wyjątkiem. Sieć komunikacyjną odbudowano i rozbudowano (linia kolejowa z Prus Wschodnich przez Taurogi i Szawle do Mitawy) na terenach Litwy i Łotwy, administrowanych przez Oberost ${ }^{17}$.

Skoro Autor pisze o tym, że „Na wstępie Niemcy uruchomili Passamt [...]", to może warto dodać, że w paszportach wystawianych przez władze okupacyjne mieszkańcom Kongresówki wpisywano, zamiast dotychczasowego "poddaństwa rosyjskiego", „poddaństwo Królestwa Polskiego”. Ponurego wizerunku okupacji Kongresówki dopełnia informacja o tym, że „obaj okupanci organizowali łapanki i zamykali ludzi w obozowych barakach otoczonych drutem kolczastym" (s. 542). Łapanki organizowano na przełomie 1915 i 1916 r. w związku z werbunkiem do pracy przymusowej w Niemczech lub na terenie okupacji austriackiej w ramach tzw. oddziałów robotników cywilnych, ale ich ofiary raczej nie trafiały za druty, w przeciwieństwie do internowanych w 1917 r. legionistów lub uczestników antyokupacyjnych manifestacji po traktacie brzeskim w 1918 r. Ci jednakże nie znaleźli się tam w rezultacie „łapanki”.

Okupacja Kongresówki stanowiła istotny przełom nie tylko ze względu na to, że „okupanci pozwolili na działalność polskich stowarzyszeń kulturalnych, oświatowych i gospodarczych [...] oraz polonizację szkolnictwa i sądownictwa". Przede wszystkim swobodę działania uzyskały partie polityczne, a polonizacja objęła także administrację, bowiem gminy same decydowały o języku urzędowania, co w praktyce oznaczało wprowadzenie języka polskiego. Językiem urzędowym władz okupacyjnych był niemiecki, ale w kontaktach ze stroną polską używano jej języka. Warto dodać, że okupanci początkowo uznali stworzony przez komitety oby-

ściu tygodni pod groźbą konfiskaty mienia. Zob. В. Мороз, Украина в двадияатом веке. Этап первый 1900-1920 г2., Москва 2005.

${ }^{16}$ A. Hausner, Die Polenpolitik der Mittelmächte und die österreichisch-ungarische Militärverwaltung in Polen während des Weltkrieges, Wien 1935, s. 362.

${ }^{17}$ P. Łossowski, Litwa, Warszawa 2001, s. 52. 
watelskie polski samorząd miejski, a następnie uregulowali jego status prawny. W obu okupacjach wprowadzono także samorząd powiatowy.

Trudno zgodzić się z opinia, że POW „na wejście do politycznej akcji” czekała do końca wojny (s. 542), bowiem od jej początku obok aktywności militarnej prowadziła działalność polityczną na szeroką skalę ${ }^{18}$.

Określenie Tymczasowej Rady Stanu (TRS) (s. 595) jako „ciała ustawodawczego" powołanego przez okupantów nie ma uzasadnienia ani $\mathrm{w}$ intencjach jej twórców, ani w jej działalności. TRS, przy całym sztafażu towarzyszącym jej inauguracji, tytulaturze władz (marszałek koronny) i strukturze organizacyjnej, była ciałem doradczym, nie bez zasług w przygotowaniach aktów prawnych przyszłego państwa polskiego. Nie liczyli się z nią okupanci, ale i w społeczeństwie polskim (i wśród samych jej członków) budziła, po początkowych nadziejach, coraz większe rozczarowanie, czego dowodziły dymisje, najpierw jej pojedynczych członków, a potem Rady jako całości ${ }^{19}$.

„Na początku grudnia [...] regenci powołali Radę Ministrów, czyli rząd, który stopniowo uzyskiwał coraz większe kompetencje. Królestwo Polskie było tworem osobliwym, gdyż obok polskich władz funkcjonowały w nim władze okupacyjne, które do końca konsekwentnie prowadziły politykę maksymalnej eksploatacji ekonomicznej jego ziem" (s. 595-596). Trudno znaleźć uzasadnienie dla "coraz większych kompetencji” rządów powoływanych przez Radę Regencyjną. Poza szkolnictwem i sądownictwem, przekazanymi przez okupantów stronie polskiej jeszcze przed powstaniem Rady Regencyjnej, inne ministerstwa nie miały realnych uprawnień i ograniczały się do kompletowania kadry urzędniczej i przygotowywania projektów aktów prawnych. Rokowania o przekazaniu przez okupantów Radzie Ministrów Królestwa Polskiego kolejnych resortów toczyły się (z przerwami) nieomalże od jej powstania do końca okupacji bez realnych rezultatów. Jeżeli coś działało obok, to raczej „polskie instytucje o charakterze państwowym" przy władzach okupacyjnych niż odwrotnie. Instytucje polskie działały głównie w Warszawie (Rada Regencyjna, Rada Ministrów, Rada Stanu od wiosny 1918 r.), natomiast w terenie były to

18 T. Nałęcz, Polska Organizacja Wojskowa 1914-1918, Wrocław 1984.

${ }^{19}$ Co do charakteru i działalności zob. m.in.: J. Pajewski, Odbudowa państwa polskiego 1914-1918, Warszawa 1978, s. 138-141, 160-169; J. Holzer, J. Molenda, Polska w pierwszej wojnie światowej, Warszawa 1973, wyd. 3, s. 261, 508 („,[...] namiastka przedstawicielstwa społeczeństwa polskiego, ciało opiniodawcze dla władz okupacyjnych[...]”). Sam Autor wcześniej pisał iż TRS to „,...] pierwsza polska instytucja o charakterze państwowym, która m. in. przygotowywała kadry urzędnicze i prawo dla nowego państwa [...]". A. Chwalba, Historia Polski 1795-1918, Kraków 2000, s. 581. 
jedynie „królewsko-polskie” sądy i tacyż powiatowi inspektorzy szkolni, przy czym jednych i drugich finansowały władze okupacyjne.

Przed kryzysem przysięgowym nie „zażądano od Piłsudskiego złożenia przysięgi na wierność obu cesarzom niemieckim" (s. 596), bowiem od 28 września 1916 r., po przyjęciu dymisji przez c. i k. władze wojskowe, Piłsudski był poza strukturami Legionów czy Polskiej Siły Zbrojnej, nie był też w lipcu 1917 r. członkiem Tymczasowej Rady Stanu. Nie zmienia to faktu, że nadal wywierał istotny wpływ na postawy legionistów, zwłaszcza I i III brygady, i to on wezwał ich do nieskładania przysięgi.

Zaletą recenzowanej pracy jest podjęcie $\mathrm{w}$ niej tematyki aspiracji narodowych „narodów Rosji”. Jednakże pewna (skądinąd zrozumiała) skrótowość ujęcia sprawia, że zatraca się specyfika poszczególnych narodów, a niektóre sądy formułowane są w sposób mało precyzyjny. Tak jest ze stwierdzeniem, że „Po marcu 1917 r. struktury państw autonomicznych zaczęli tworzyć Litwini, Łotysze, Estończycy, Finowie, narody Kaukazu, Azerowie, Ormianie, Gruzini oraz Ukraińcy, a nawet Białorusini". Otóż sytuacja tych narodów, ograniczając się tylko do europejskiej części Imperium Rosyjskiego, nie była identyczna. Etniczne ziemie litewskie były od jesieni 1915 r. w całości okupowane przez wojska niemieckie i, jak sam Autor pisze, Rada Litewska (Taryba) powstała, za zgodą władz okupacyjnych, dopiero w drugiej połowie września 1917 r. i chyba trudno traktować jac jako „strukturę państwa autonomicznego". Ziemie białoruskie i łotewskie były w marcu 1917 r. podzielone linią frontu, a najbardziej skomplikowana sytuacja panowała na ziemiach zamieszkanych przez Ukraińców (Rusinów). Finlandia i Estonia w 1917 r. były na zapleczu frontu, przy czym Finowie posiadali instytucje autonomiczne przez cały okres panowania rosyjskiego. Estończycy w pełni wykorzystali warunki stworzone przez rewolucję marcową do budowy własnych struktur państwowych (parlament, rząd, administracja, siły zbrojne) w granicach pomarcowej Rosji.

„Nieco trudniej było Łotyszom i Estończykom, którzy po rewolucji marcowej tworzyli administracyjne struktury autonomiczne $\mathrm{w}$ ramach Rosji. Jedni i drudzy zaczęli formować własne jednostki zbrojne, które na przełomie 1917 i 1918 walczyły z wojskami bolszewickimi" (s. 607). Rzecz jest bardziej skomplikowana, bowiem formacje łotewskich strzelców przy armii rosyjskiej zaczęto tworzyć już w lecie $1915 \mathrm{r}$. i w tym samym roku walczyły one z wojskami niemieckimi koło Rygi. Po krwawych, okupionych ogromnymi stratami (37\% stanów) walkach na przełomie 1916 i 1917 r. nastąpiła radykalizacja nastrojów w tych formacjach i podatność na bolszewicką agitację, czego skutkiem było, po rewolucji lutowej, powołanie rad żołnierskich i komitetu wykonawczego tych rad. Bolszewicy triumfowali też $\mathrm{w}$ wyborach do różnego rodzaju ciał przedstawicielskich, 
poczynając od ogólnorosyjskiej Konstytuanty (72\%), a kończąc na radzie miejskiej Rygi (41\%). Nieśmiałe próby łotewskich polityków uzyskania dla kraju statusu autonomicznego, jaki miała Estonia, zostały odrzucone przez rosyjski Rząd Tymczasowy i żadne łotewskie „administracyjne struktury autonomiczne" w 1917 r. nie powstały. Od października $1917 \mathrm{r}$. dotychczasowe łotewskie formacje zbrojne to "czerwoni łotewscy strzelcy" walczący po stronie bolszewików. Stanowili oni m. in. ochronę Smolnego, a dywizja łotewska (ok. 23 tys. żołnierzy w jesieni 1918 r.) była pierwszą regularną jednostką Armii Czerwonej i walczyła na różnych frontach wojny domoweje ${ }^{20}$.

W Estonii formowanie własnych sił zbrojnych rozpoczęto wiosną 1917 r. i w końcu 1917 r. była to 1. Dywizja Estońska. Jej 1. pułk poniósł duże straty we wrześniu 1917 r. w walce z wojskami niemieckimi na wyspie Muhu. Po względnie łagodnym przewrocie bolszewickim w Estonii przez pewien czas funkcjonowały obok instytucji radzieckich dotychczasowe estońskie struktury państwowe, w tym także 1. Dywizja Estońska. Próby opanowania jej poszczególnych pułków przez bolszewików powiodły się w niewielkim stopniu i rozformowały ją dopiero w marcu $1918 \mathrm{r}$. niemieckie władze okupacyjne. Żołnierze estońscy sporadycznie tylko walczyli z bolszewikami, m. in. uwalniając w Tartu w listopadzie $1917 \mathrm{r}$. aresztowanego przez czerwonych łotewskich strzelców Jaana Tõnissona czy w lutym 1918 r., przed proklamacją niepodległości, kiedy wsparły antybolszewickie powstania $\mathrm{w}$ większych miastach. W powstaniach tych istotną rolę odegrała też paramilitarna Samoobrona (Omakaitse) ${ }^{21}$.

"Najbardziej dojrzały w regionie projekt państwa narodowego stworzyli Litwini, dopingowani aktem 5 listopada i rosyjską rewolucją" (s. 597). Bez skonkretyzowania, o jaki „projekt” chodzi, trudno ocenić, czy był on "najbardziej dojrzały”.

Ewidentną pomyłką jest ulokowanie I Korpusu Polskiego gen. Dowbora Muśnickiego na Ukrainie (s. 604), a wcześniej (s. 460) niezbyt zręczne sformułowanie sugerujące, że korpusy polskie w Rosji formowano $\mathrm{z}$ jeńców ${ }^{22}$. Podobnie jest $\mathrm{z}$ informacją zawartą w zdaniu: „Oba zwycięskie na Wschodzie państwa, likwidując rządy rosyjskie, zaprowadziły okupacyjną administrację wojenna, Naczelne Dowództwo Wschodu, w skrócie Oberost [...]" (s. 593). Otóż Oberost (Oberbefehlshaberost, pisany także

${ }^{20}$ История Латвиu, Рига 2005, s. 70-88.

${ }^{21}$ T. Paluszyński, Walka o niepodległość Estonii 1914-1920, Poznań 2007, s. 64177.

${ }^{22}$ „Z k kolei jeńcy polscy nad Sekwaną współtworzyli armię, której wodzem został generał Józef Haller, a w Rosji po rewolucji marcowej formowano polskie korpusy i pułki". 
jako Ober-Ost), powołany 4 listopada 1915 r., obejmował tylko obszary okupowane przez armię niemiecką na wschód od Generalnego Gubernatorstwa Warszawskiego. Tereny zajęte przez armię austro-węgierską miały własną administrację okupacyjną, całkowicie niezależną od OberOstu $^{23}$.

Skoro Autor pisze o udanych (gen. Ł. Korniłow) i nieudanych (kpt. Ch. de Gaulle) ucieczkach z niewoli, to może warto wspomnieć o głośnej już w czasie wojny ucieczce z niewoli rosyjskiej oficera c. i k. armii Franciszka Seweryna Włada. Jeńcem został w roku 1914 i po udanej ucieczce do Chin wrócił w 1916 r. w szeregi armii austro-węgierskiej. Karierę wojskową zakończył jako dowódca 14. Wielkopolskiej Dywizji Piechoty WP, 18 września 1939 r., śmiertelnie ranny w bitwie nad Bzurą.

Pisząc o tym, że „Ukraińcy [służyli] w rosyjskiej, austro-węgierskiej oraz w węgierskiej armii honwedów" (s. 582), należałoby dodać, że także w austriackiej obronie krajowej.

„Niemcy austriaccy z Czech" (s. 590) to zbitka pojęciowa, której nie było w czasie I wojny . W statystykach c. i k. monarchii byli Niemcy ${ }^{24}$, natomiast jeżeli chciano podkreślić także ich miejsce zamieszkania, dodawano odpowiedni przymiotnik (Niemcy austriaccy, czescy). Nie było narodowości austriackiej. Jeżeli używano słowa "Austriak" to dla określenia przynależności państwowej do przedlitawskiej części podwójnej monarchii, a nie narodowej. Stąd nie jest precyzyjne sformułowanie, że „zniemczony Chorwat Svetozar Boroević von Bojna [to] jedyny nie-Austriak w tak wysokiej randze" (s. 202). W ówczesnych kategoriach to raczej nie-Niemiec.

W indeksie nazwisk obok „Pless Maria Teresa Oliwia Hochberg von (Daisy)” jest też „Pless von, ród”. Otóż ród nosił i używał nazwiska Hochberg (pełny tytuł Fürst von Pless, Reichsgraf von Hochberg, Freiherr zu Fürstenstein).

Trudno mówić o „powrocie na polityczną scenę” (s. 622) Estończyków czy Łotyszy, którzy dopiero w 1918 r. stworzyli własne suwerenne państwa.

Stwierdzenie, że „[...] ludność cywilna nie poniosła, poza Ormianami i Serbami, większych ofiar, a jeśli już, to prawie wyłącznie w strefie frontowej i przyfrontowej" - budzi wątpliwości. Straty ludności cywilnej

${ }^{23}$ Szerzej o austro-węgierskim zarządzie okupacyjnym w poszczególnych krajach: Die Militärvwerwaltung in den von den österreichisch-ungarischen Truppen besetzten Gebieten, Wien 1928.

${ }_{24}$ Österreichisches Statistisches Handbuch für die im Reichsrate vertretenen Königreiche und Länder, Wien (różne roczniki). 
to tragedia milionów ewakuowanych („,bieżeńców”), umierających na wygnaniu albo w czasie drogi w głąb Rosji czy Austro-Węgier, bądź też w trakcie drogi powrotnej. To bezpośrednie bądź pośrednie ofiary głodu, niedożywienia i tragicznych warunków bytowych, podatne na szerzące się choroby zakaźne, zbierające śmiertelne żniwo we wszystkich latach wojny. To także $\mathrm{m}$. in. niższy przyrost naturalny i wyższa niż w czasach pokoju śmiertelność ludności cywilnej.

Strona wydawnicza nie ułatwia korzystania z pracy. Rozrzucone $\mathrm{w}$ tekście ilustracje nie posiadają numeracji ani spisu. Brak indeksu miejscowości w pracy, w której występuje kilkaset nazw geograficznych, to istotny mankament.

Podstawowa bibliografia obejmuje kilkadziesiąt pozycji z ostatnich około trzydziestu lat (większość wydana po roku 2000), w tym tylko jedną w języku niemieckim.

Czytelnik otrzymał obszerne, nowatorskie, interesująco napisane opracowanie dziejów I wojny światowej, uwzględniające nowe obszary badawcze, ale też zawierające wiele potknięć i opinii nie zawsze znajdujących potwierdzenie w bogatej, wielojęzycznej, liczącej też już blisko sto lat, starszej i nowszej historiografii przedmiotu.

Jan Lewandowski

(emerytowany prof. Instytutu Historii UMCS w Lublinie)

\section{BIBLIOGRAFIA:}

Bator J., Wojna galicyjska. Działania armii austro-węgierskiej na froncie pótnocnym (galicyjskim) w latach 1914-1915, Kraków 2005.

Batowski H., Rozpad Austro-Węgier 1914-1918. (Sprawy narodowościowe i działania dyplomatyczne), wyd. 2, Kraków 1982.

Chwalba A., Historia Polski 1795-1918, Kraków 2000.

Dąbrowski J., Wielka wojna 1914-1918 na podstawie najnowszych źródet, t. 1-2, Warszawa 1937.

Die Militärvwerwaltung in den von den österreichisch-ungarischen Truppen besetzten Gebieten, Wien 1928.

Hanusch F., Die Regelung der Arbeiterverhältnisse im Kriege, Wien 1927.

Hausner A., Die Polenpolitik der Mittelmächte und die ősterreichisch-ungarische Militärverwaltung in Polen während des Weltkrieges, Wien 1935.

Holzer J., Molenda J., Polska w pierwszej wojnie światowej, wyd. 3, Warszawa 1973.

Izdebski E., Bitwa pod Komarowem. 26 sierpnia-2 września 1914 r., Warszawa 1931.

Izdebski E., Bitwa pod Zamościem 26-27 sierpnia 1914 r., „Bellona” 1929, t. 33.

Loewenfeld-Russ H., Die Regelung der Volksernährung im Kriege, Wien 1926.

Łossowski P., Litwa, Warszawa 2001.

Najdus W., Galicja w pierwszym roku działań wojennych, [w:] Historia Polski, t. 3, cz. 3, 19141918 red. Ż. Kormanowa i W. Najdus, Warszawa 1974. 
Nałęcz T., Polska Organizacja Wojskowa 1914-1918, Wrocław 1984.

Osadczy W., Święta Ruś. Rozwój i oddziaływanie idei prawosławia w Rosji, Lublin 2007.

Pajewski J., Odbudowa państwa polskiego 1914-1918, Warszawa 1978.

Pajewski J., Pierwsza wojna światowa 1914-1918, Warszawa 1991.

Paluszyński T., Walka o niepodległość Estonii 1914-1920, Poznań 2007.

Plaschka R. G., Haselssteiner H., Suppan A., Innere Front. Militärassistenz, Widerstand und Umsturz in der Donaumonarchie 1918, Bd. 1-2, Mǘnchen 1974.

Polska w czasie Wielkiej Wojny, t. 2-4, red. M. Handelsman, Warszawa 1932-1939.

Vojcechovsky S., Bitwa u Tomaszowa a Komarowa, Praha 1935.

Wereszycki H., Historia Austrii, Wrocław 1972.

Белой А., Галицийская битва, Москва-Денинград 1929; Österreich-Ungarns letzter Krieg 1914-1918, 2 Aufl., Bd. 1, Wien 1931.

История Иатвии, Рига 2005.

Мороз В., Украина в двадизатом веке. Этап первый 1900-1920 г2., Москва 2005. 